\title{
PROBLEMATIKA DAERAH KERJA PEJABAT PEMBUAT AKTA TANAH
}

\author{
Andri Pranata \\ Fakultas Hukum UWGM Samarinda \& Kepala Bidang \\ Non LItigasi LKBH UWGM Samarinda \\ andrivpranata@gmail.com
}

\begin{abstract}
ABSTRAK
Dalam Pelaksanaan tugas dan wewenangnya, PPAT harus memiliki dasar hukum untuk memberikan jaminan kepastian hukum dan perlindungan hukum baik bagi PPAT itu sendiri maupun bagi masyarakat. Dalam pelaksanaan tugas dan wewenang itu, PPAT telah memiliki peraturan yang mengatur segala sesuatu tentang PPAT, mulai dari syarat, tugas, kewajiban, larangan, akta yang dibuat, wilayah kerja PPAT dan lain-lain. Peraturan tersebut dibuat oleh pemerintah sebagai upaya untuk memberikan kepastian hukum dan perlindungan hukum bagi PPAT maupun bagi masyarakat. Pada tahun 2016 pemerintah mengeluarkan Peraturan Pemerintah Nomor 24 Tahun 2016 tentang Perubahan Peraturan Pemerintah Nomor 37 Tahun 1998 tentang Peraturan Jabatan Pembuat Akta Tanah (selanjutnya disebut PP 24), dengan diterbitkannya PP 24 tersebut. Ada beberapa perubahan, salah satunya tentang daerah kerja PPAT, dari Kabupaten/Kota menjadi Satuan Wilayah Provinsi akan tetapi saat ini dalam praktiknya terkait daerah kerja tersebut tidak dapat dilaksanakan. Berdasarkan uraian tersebut mengapa PP 24 Terkait Daerah Kerja PPAT tidak dilaksanakan dan bagaimana Peran IPPAT terkait PP 24 tersebut. Metode Penelitian ini adalah normatif yaitu penelitian yang dilakukan melalui studi kepustakaan. Penelitian hukum normatif berdasarkan data sekunder lalu di kelola dan di analisis menggunakan analisis deskriptif-kualitatif. Pasal 12 ayat (1) dalam PP 24 belum dapat dilaksanakan karena PPAT sendiri maunya tetap kepada Peraturan Pemerintah Nomor 37 Tahun 1998 tentang Peraturan Jabatan Pembuat Akta Tanah yaitu Kabupaten/Kota masih banyak yang perlu dipersiapkan serta peran IPPAT sejauh ini dalam pembentukan PP 24 yaitu IPPAT memberikan masukan tentang permasalahan dalam praktik yang dilakukan oleh PPAT kepada Kementerian ATR/BPN RI.
\end{abstract}

Kata kunci: Problematika, Daerah Kerja, Pejabat Pembuat Akta Tanah

\section{ABSTRACT}

In performing his duty and authority, a Land Title Registrar (PPAT) must have a law foundation to provide law security and protection, either of the PPAT or for the community. In the duty, PPAT has the regulations organizing PPAT matters which were made by the government. In 2016, government issued Government Regulation Number 24 Year 2016 on Government Regulation Change Number 37 Year 1998 on Position Regulations of Land Title Registrar, called PP 24. One of the changes is PPAT working area. However, in the practice, it cannot be performed. The study method is normative done through reference study based on secondary data processed by using descriptive-qualitative analysis. Article 12 verse (1) in PP 24 cannot be performed yet since PPAT wants to stay in Government Regulation 37 Year 1998 above that is PPAT gives input on the practice problem of PPAT to the Ministry of Agrarian and Landscape/BPN RI.

Key words: Problematic, Working area, Land Titles Registrar 


\section{PENDAHULUAN}

Awal mula eksistensi jabatan PPAT diatur dalam ketentuan Pasal 19 Peraturan Pemerintah Nomor 10 Tahun 1961 tentang Pendaftaran Tanah serta hak dan kewajibannya yang menegaskan bahwa setiap perbuatan hukum pemindahan hak atas tanah harus dilakukan para pihak dihadapan pejabat yang ditunjuk oleh Menteri selanjutnya diatur dalam Peraturan Menteri Agraria Nomor 11 Tahun 1961 tentang Penunjukan Pejabat yang dimaksudkan dalam Pasal 19 Peraturan Pemerintah Nomor 10 Tahun 1961 bahwa pejabat yang dimaksud adalah PPAT.

Seiring dengan perkembangannya kehidupan masyarakat kedudukan PPAT sebagai pejabat umum yang berwenang membuat akta otentik berkaitan dengan pertanahan dikukuhkan dalam Undang-Undang Nomor 4 Tahun 1996 tentang Hak Tanggungan dan Peraturan Pemerintah Nomor 24 Tahun 1997 tentang Pendaftaran Tanah serta Peraturan Pemerintah Nomor 37 Tahun 1998 tentang Peraturan Jabatan Pejabat Pembuat Akta Tanah (selanjutnya disebut PP 37). ${ }^{1}$

Maksud ditetapkannya PPAT adalah untuk membantu tugas Pemerintah dalam melaksanakan pendaftaran tanah sebagaimana diamanatkan Pasal 19 Undang-Undang Nomor 5 Tahun 1960 tentang Peraturan Dasar Pokok-Pokok Agraria (UUPA). Kemudian menurut Pasal 1 PP 37 yang dimaksud dengan PPAT yaitu pejabat umum yang diberi kewenangan untuk membuat akta-akta autentik mengenai perbuatan hukum tertentu mengenai hak atas tanah atau hak milik atas satuan rumah susun.

Sejak diterbitkannya Undang-Undang Nomor 5 Tahun 1960 yang mengatur tentang Peraturan Dasar Pokok-Pokok Agraria (UUPA), kemudian diterbitkan suatu Peraturan Pemerintah tentang Pejabat Pembuat Akta Tanah dengan PP 37 sebagaimana pelengkap dari Peraturan Pemerintah tentang Pendaftaran Tanah dan telah dijanjikan pada Pasal 7 Peraturan Pemerintah Nomor 24 Tahun 1997 tentang Pendaftaran Tanah. Tugas dan ruang lingkup jabatan PPAT tidak secara jelas dan rinci diatur. Menimbulkan keragu-raguan dan tidak teraturnya dengan peraturan hukum tertentu, sehingga menimbulkan kekacauan.

Sejak tahun 1961 hingga diterbitkannya PP 37 telah banyak kekacauan dan kesalahankesalahan dalam pelaksanaan pembuatan akta PPAT tidak tertuang dalam PMA Nomor 18

\footnotetext{
${ }^{1}$ Samsaimun, Peraturan Jabatan PPAT, Pengantar Peraturan Jabatan Pejabat Pembuat Akta Tanah (PPAT) dalam peralihan Hak atas Tanah di Indonesia, (Bandung; Pustaka Reka Cipta, 2018), hlm 1-2.
} 
Tahun 1961. PMA Nomor 10 Tahun 1961 yang terdiri atas 10 pasal hanya mengatur tentang Daerah Kerja PPAT, tentang kewenangan membuat akta tanah dalam daerah kerjanya dan keharusan meminta izin jika melakukan pembuatan akta tanah dilain daerah kerjanya yang berkantor di daerah kerjanya, kemudian siapa yang dapat diangkat sebagai PPAT. Setelah dikeluarkannya PP 37, tugas dan ruang lingkup jabatan PPAT lebih jelas dan rinci meskipun kalangan akademisi masih mempertanyakan keabsahan atau keautentikan dari akta yang dibuat PPAT.

Lalu pada tahun 2016, pemerintah mengeluarkan Peraturan Pemerintah Nomor 24 Tahun 2016 tentang Perubahan Peraturan Pemerintah Nomor 37 Tahun 1998 tentang Peraturan Jabatan Pembuat Akta Tanah (selanjutnya disebut PP 24) yang pada dasarnya disambut baik, karena dengan diterbitkannya PP 24 telah menimbulkan kepastian terhadap daerah kerja PPAT, sehingga daerah kerja PPAT menjadi sama dengan Wilayah Jabatan Notaris. Hal ini dapat mencegah terjadinya kasus-kasus monopoli daerah kerja pembuatan Akta dengan meminta nomor akta kepada PPAT lain yang berada di daerah kerja tempat tanah akan dibuatkan akta.

Namun yang menjadi polemik hingga saat ini adalah PP 24 terkait daerah kerja tersebut yang hingga saat ini tidak dapat dilaksanakan. Dalam Pasal 12 ayat (1) PP 24 mengenai Daerah Kerja PPAT yang diubah, bahwa daerah kerja PPAT adalah satu wilayah provinsi, yang sebelumnya. dalam Pasal 12 ayat (1) PP 37 bahwa daerah kerja PPAT adalah satu wilayah kerja kantor Pertanahan Kabupaten/Kotamadya. Padahal telah diundangkan sejak tahun 2016 bahkan telah diumumkan dalam Lembaran Negara Nomor 5893 yang artinya Peraturan Pemerintah tersebut telah berlaku sebagai Undang-Undang dan wajib untuk dilaksanakan.

Apabila Peraturan Pemerintah masih belum bisa dilaksanakan yang menjadi pertanyaan kendala dari Peraturan Pemerintah tersebut karena sampai saat ini, statusnya masih tidak jelas, karena dalam prakteknya meskipun Peraturan Pemerintah ini telah diundangkan akan tetapi hingga saat ini PP 24 diberlakukan tidak, di cabut juga tidak. 


\section{PENDEKATAN TEORI}

\section{A. Asas-Asas Hukum Yang Berlaku}

Dalam pembentukan Peraturan Perundang-undangan dikenal beberapa asas umum, antara lain: ${ }^{2}$

Pertama, Undang-Undang tidak berlaku surut. Asas ini dapat dibaca dalam Pasal 13 Algemene Bepalingen van Wetgeving (selanjutnya disebut A.B.) yang terjemahannya berbunyi "Undang-undang hanya mengikat untuk masa mendatang dan tidak mempunyai kekuatan yang berlaku surut." Pasal 1 Ayat (1) Kitab Undang-Undang Hukum Pidana, yang berbunyi "Tiada peristiwa dapat dipidana, kecuali atas dasar kekuatan suatu aturan perundang-undangan pidana yang mendahulukan." Artinya dari asas ini adalah, bahwa undang-undang hanya boleh dipergunakan terhadap peristiwa yang disebut dalam undang-undang tersebut, dan terjadi setelah undang-undang dinyatakan berlaku.

Kedua, Undang-undang yang tidak dapat diganggu gugat. Makna asas ini sebagai berikut:

1. Adanya kemungkinan isi undang-undang menyimpang dari Undang-Undang Dasar; dan

2. Hakim atau siapapun juga tidak mempunyai hak uji materiil terhadap undangundang tersebut. Hak tersebut hanya dimiliki oleh pembuat undang-undang.

Ketiga, Undang-Undang sebagai sarana untuk semaksimal mungkin untuk mencapai kesejahteraan spiritual dan materiil bagi masyarakat maupun individu, melalui pembaharuan (asas welvarstaat).

Keempat, Undang-undang yang lebih tinggi mengesampingkan undang-undang yang lebih rendah (lex superiori derogate lex inferiori). Menurut asas ini bahwa peraturan perundang-undangan yang lebih rendah tingkatannya tidak boleh bertentangan dengan Peraturan Perundang-Undangan yang lebih tinggi dalam mengatur hal yang sama. Konsekuensi hukum asas lex superiori derogate lex inferiori ialah:

1. Undang-Undang yang dibuat oleh penguasa yang lebih tinggi mempunyai kedudukan yang lebih tinggi pula;

2. Undang-Undang yang lebih rendah tidak boleh bertentangan dengan UndangUndang yang lebih tinggi; ${ }^{3}$

3. Perundang-undangan hanya dapat dicabut, diubah, atau ditambah oleh atau dengan peraturan perundang-undangan yang sederajat atau yang lebih tinggi tingkatannya. Tidak ditaatinya asas tersebut akan dapat menimbulkan ketidaktertiban dan ketidakpastian dari system perundang-undangan. Bahkan dapat menimbulkan kekacauan atau kesimpangsiuran perundang-undangan. ${ }^{4}$

Kelima, Undang-Undang yang bersifat khusus mengesampingkan undang-undang yang bersifat umum (lex specialis derogate lex generalis). Menurut asas ini apabila

\footnotetext{
${ }^{2}$ Ni'matul Huda, Teori \& Pengujian Peraturan Perundang-Undangan, (Bandung; Nusamedia, 2011), hlm 12.

${ }^{3}$ Umar Said Sugiarto, Pengantar Hukum Indonesia, (Jakarta; Sinar Grafika, 2016), hlm 62.

${ }^{4}$ Amiroeddin Sjarif, Perundang-Undangan (Dasar,Jenis,dan Teknik Membuatnya), (Bandung: Rineka Cipta, 1987), hlm 78-79.
} 
ada dua macam ketentuan peraturan perundangan yang setingkat atau kedudukannya sama dan berlaku dalam waktu yang bersamaan serta saling bertentangan, maka hakim harus menerapkan atau menggunakan yang khusus sebagai dasar hukum, dan mengesampingkan yang umum. ${ }^{5}$

Keenam,undang-undang yang berlaku belakangan membatalkan undang-undang terdahulu (lex posteriori derogate lex priori). Maksudnya adalah undang-undang atau peraturan yang terdahulu (lama) menjadi tidak berlaku apabila penguasa yang berwenang memberlakukan undang-undang atau peraturan yang baru dalam hal mengatur objek yang sama, dan kedudukan undang-undang atau peraturannya sederajat. $^{6}$

Lebih jauh menurut Purnadi Purbacaraka/Surjono Sukanto ${ }^{7}$ terdapat 6 asas perundangundangan:

1. Undang-undang tidak berlaku surut.

2. Undang-undang yang dibuat penguasa lebih tinggi mempunyai kedudukan lebih tinggi pula.

3. Undang-undang yang bersifat khusus mengesampingkan undang-undang yang bersifat umum.

4. Undang-undang yang berlaku belakangan (baru) mengesampingkan undangundang yang berlaku terdahulu.

5. Undang-undang tidak dapat diganggu gugat.

6. Undang-undang berorientasi mencapai kesejahteraan spritual dan material.

Sementara itu menurut Amirudin Syarif ${ }^{8}$ terdapat 5 asas Perundang-undangan yaitu:

1. Asas tingkatan hierarki.

2. Asas undang-undang tidak dapat diganggu gugat.

3. Asas undang-undang bersifat khusus mengesampingkan undang-undang bersifat umum.

4. Asas undang-undang tidak berlaku surut.

5. Undang-undang yang baru mengesampingkan undang-undang yang lama.

Terutama dalam Undang-Undang Nomor 12 tahun 2011 terdapat asas-asas pembentukan peraturan perundang-undangan sebagai berikut: ${ }^{9}$

1. Asas kejelasan tujuan maksudnya; bahwa setiap pembentukan Peraturan Perundang-undangan harus mempunyai tujuan yang hendak dicapai.

2. Asas Ieelembagaan atau organ pembentukyang tepat; bahwa setiap jenis Peraturan Perundang-undangan harus dibuat oleh lembaga atau pejabat pembentuk Peraturan Perundangundangan yang berwenang. Dan Peraturan Perundangundangan ini dapat batal demi hukum jika dibuat oleh lembaga atau pejabat yang tidak berwenang.

${ }^{5}$ Umar Said Sugiarto, Op.cit., hlm 64.

6/bid., hlm 64-65.

${ }^{7}$ Nomensen Sinamo, /lmu Perundang-Undangan, (Jakarta: Jala Permata Aksara, 2016), hlm 49.

$8 /$ bid., hlm 50.

${ }^{9}$ bid., hlm 51-52. 
3. Asas kesesuaian antara jenis dan materi muatan; bahwa dalam Pembentukan Peraturan Perundang-undangan harus benarbenar memperhatikan materi muatan yang tepat dengan jenis Peraturan Perundang-undangannya.

4. Asas dapat dilaksanakan; bahwa setiap pembentukan Peraturan Perundangundangan harus memperhatikan efektivitas Peraturan Perundang-undangan tersebut didalam masyarakat, baik secara filosofis, yuridis maupun sosiologis.

5. Asas kedayagunaan dan kehasilgunaan; bahwa setiap Peraturan Perundangundangan dibuat karena memang benar-benar

6. Asas bhinneka tunggal ika; adalah bahwa materi muatan peraturan perundangundangan harus memperhatikan beragam penduduk, agama, suku dan golongan, kondisi khusus daerah serta budaya dalam kehidupan bermasyarakat, berbangsa dan bernegara.

7. Asas keadilan; adalah bahwa setiap materi muatan peraturan perundang-undangan harus mencerminkan keadilan secara proporsional bagi setiap warga negara.

8. Asas kesamaan kedudukan dalam hukum dan pemerintahan; adalah bahwa setiap materi muatan peraturan perundangundangan tidak boleh memuat hal yang bersifat membedakan berdasarkan latar belakang, antara lain agama, suku, ras, golongan, gender, atau status sosial.

9. Asas ketertiban dan kepastian hukum; adalah bahwa setiap materi muatan peraturan perundang-undangan harus dapat mewujudkan ketertiban dalam masyarakat melalui jaminan kepastian hukum.

10. Asas keseimbangan, keserasian, dan keselarasan; adalah bahwa setiap materi muatan peraturan perundang-undangan harus mencerminkan keseimbangan, keserasian, dan keselarasan, antara kepentingan individu, masyarakat dan kepentingan bangsa dan negara.

\section{B. Teori Kepastian Hukum}

Menurut Hans Kelsen, hukum adalah sebuah sistem norma. Norma adalah pernyataan yang menekankan aspek "seharusnya" atau das sollen, dengan menyertakan beberapa peraturan tentang apa yang harus dilakukan. Norma-norma adalah produk dan aksi manusia yang deliberatif. Undang-Undang yang berisi aturan-aturan yang bersifat umum menjadi pedoman bagi individu bertingkah laku dalam bermasyarakat, baik dalam hubungan dengan sesama individu maupun dalam hubungannya dengan masyarakat. Aturan-aturan itu menjadi batasan bagi masyarakat dalam membebani atau melakukan tindakan terhadap individu. Adanya aturan itu dan pelaksanaan aturan tersebut menimbulkan kepastian hukum. ${ }^{10}$

Menurut Utrecht, kepastian hukum mengandung dua pengertian, yaitu pertama, adanya aturan yang bersifat umum membuat individu mengetahui perbuatan apa yang boleh atau tidak boleh dilakukan, dan kedua, berupa keamanan hukum bagi individu dari kesewenangan pemerintah karena dengan adanya aturan yang bersifat umum itu individu

\footnotetext{
${ }^{10}$ Peter Mahmud Marzuki, Pengantar /lmu Hukum, (Jakarta; Kencana, 2008), hlm 158.
} 
dapat mengetahui apa saja yang boleh dibebankan atau dilakukan oleh negara terhadap individu. ${ }^{11}$

Ajaran kepastian hukum ini berasal dari ajaran yuridis-dogmatik yang didasarkan pada aliran pemikiran positivistis di dunia hukum, yang cenderung melihat hukum sebagai sesuatu yang otonom, yang mandiri, karena bagi penganut pemikiran ini, hukum tak lain hanya kumpulan aturan. Bagi penganut aliran ini, tujuan hukum tidak lain dari sekedar menjamin terwujudnya kepastian hukum. Kepastian hukum itu diwujudkan oleh hukum dengan sifatnya yang hanya membuat suatu aturan hukum yang bersifat umum. Sifat umum dari aturan-aturan hukum membuktikan bahwa hukum tidak bertujuan untuk mewujudkan keadilan atau kemanfaatan, melainkan semata-mata untuk kepastian. ${ }^{12}$

Kepastian hukum merupakan jaminan mengenai hukum yang berisi keadilan. Normanorma yang memajukan keadilan harus sungguh-sungguh berfungsi sebagi peraturan yang ditaati. Menurut Gustav Radbruch keadilan dan kepastian hukum merupakan bagian-bagian yang tetap dari hukum. Beliau berpendapat bahwa keadilan dan kepastian hukum harus diperhatikan, kepastian hukum harus dijaga demi keamanan dan ketertiban suatu negara. Akhirnya hukum positif harus selalu ditaati. Berdasarkan teori kepastian hukum dan nilai yang ingin dicapai yaitu nilai keadilan dan kebahagiaan. ${ }^{13}$

\section{METODE PENELITIAN}

Penelitian ini merupakan penelitian hukum normatif, Penelitian hukum normatif adalah penelitian yang dilakukan melalui studi kepustakaan dalam mencari data sumber yang bersifat teori yang berguna untuk memecahkan masalah. Pendekatan ini dikenal dengan nama pendekatan kepustakaan atau yang biasa disebut dengan studi kepustakaan, yakni dengan mempelajari buku-buku, peraturan perundangan-undangan dan dokumentasi lainnya yang berhubungan dengan penelitian ini. ${ }^{14}$

Dalam penelitian ini juga menggunakan pendekatan konsep (Conceptual approach), yang memberikan sudut pandang analisa penyelesaian permasalahan dalam penelitian hukum dilihat dari aspek konsep-konsep hukum yang melatarbelakanginya, atau bahkan dapat dilihat dari nilai-nilai yang terkandung dalam pernormaan sebuah peraturan kaitannya

\footnotetext{
${ }^{11}$ Riduan Syahrani, Rangkuman /ntisari /lmu Hukum, (Bandung; Citra Aditya Bakti, 1999), hlm 23.

${ }^{12}$ Achmad Ali, Menguak Tahir Hukum (Suatu Ka)ian Filosofis dan Sosiologis), Jakarta, Toko Gunung Agung, 2002), hlm 82-83.

13 /hid., hlm 95.

${ }^{J 4}$ Muhammad Abdulkadir, Hukum dan Penelitian Hukum, (Bandung; Citra Aditya Bakti, 2004), hlm. 201.
} 
dengan konsep-konsep yang berkaitan dengan pernormaan dalam suatu perundangperundangan.

Pandangan/doktrin akan memperjelas ide-ide dengan memberikan pengertianpengertian hukum, konsep hukum, maupun asas hukum yang relevan dengan permasalahan. Penelitian hukum normatif berdasarkan data sekunder.

Pendekatan masalah yang digunakan dalam penelitian ini menggunakan metode pendekatan perundang-undangan (Statute approach). Dalam menggunakan pendekatan Perundang-undangan (Statue approach). Dalam penelitian ini, peneliti menggunakan metode penyajian dengan analisis deskriptif kualitatif.

\section{HASIL PENELITIAN}

\section{A. Alasan-alasan PP 24 tidak dilaksanakan}

Dalam pelaksanaan tugas dan wewenangnya, PPAT harus memiliki dasar hukum untuk memberikan jaminan kepastian hukum dan perlindungan hukum baik bagi PPAT itu sendiri maupun bagi masyarakat. Dalam pelaksanaan tugas dan wewenang itu, PPAT telah memiliki peraturan-peraturan yang mengatur tentang segala sesuatu tentang PPAT, mulai dari syarat, tugas, kewajiban, larangan, akta yang dibuat, wilayah kerja PPAT dan lain-lain. Peraturan tersebut dibuat oleh pemerintah sebagai upaya untuk memberikan kepastian hukum dan perlindungan hukum baik bagi PPAT maupun bagi masyarakat.

Pada tahun 2016 pemerintah mengeluarkan PP 24, dengan diterbitkannya PP 24 tersebut, ada beberapa perubahan dalam peraturan pemerintah tersebut, salah satunya tentang daerah kerja PPAT, berdasarkan PP 37 bahwa daerah kerja PPAT yaitu Kabupaten/Kotamadya sedangkan dalam PP 24 Daerah Kerja PPAT yaitu Satuan Wilayah Provinsi dengan ini daerah kerja PPAT menjadi sama dengan Wilayah Jabatan Notaris akan tetapi saat ini dalam praktiknya PP 24 terkait daerah kerja tersebut tidak dapat dilaksanakan, mengingat bahwa peraturan pemerintah ini telah diundangkan sejak tahun 2016 bahkan telah diumumkan dalam Lembaran Negara Nomor 5893 yang artinya Peraturan Pemerintah tersebut telah berlaku sebagai Undang-Undang dan wajib untuk dilaksanakan.

Jika masih satu wilayah kerja Kantor Pertanahan Kabupaten/Kotamadya berdasarkan PP 37 maka hal ini bertentangan dengan asas lex posteriori derogate lex priori, bahwa Undang-Undang yang berlaku belakangan membatalkan undang-undang terdahulu sejauh Undang-Undang itu mengatur hal yang sama. 
Berdasarkan hal tersebut seharusnya Pasal 12 ayat (1) dalam PP 37 tidak berlaku lagi karena telah dirubah dengan Pasal 12 ayat (1) PP 24, maka seharusnya saat ini daerah kerja PPAT berdasarkan Pasal 12 ayat (1) PP 24 adalah Satuan Wilayah Provinsi, karena UndangUndang atau peraturan yang terdahulu (lama) menjadi tidak berlaku apabila penguasa yang berwenang memberlakukan Undang-Undang atau peraturan yang baru dalam hal mengatur objek yang sama, dan kedudukan Undang-Undang atau peraturannya sederajat.

Menurut Peter Mahmud Marzuki berpendapat sebagai berikut:

"Asas lex posterior derogat legi priori menghendaki bahwa peraturan perundangundangan yang terkemudian menyisihkan peraturan perundang-undangan yang terdahulu. Penggunaan asas ini mensyaratkan bahwa yang dihadapkan adalah dua peraturan perundang-undangan dalam hierarki yang sama. Adanya asas ini dapat dipahami mengingat peraturan perundang-undangan yang baru lebih mencerminkan kebutuhan dan situasi yang sedang berlangsung".

Pendapat lain mengenai ini yaitu menurut Bagir Manan sebagaimana dikutip oleh A.A. Oka Mahendra menyatakan bahwa asas lex posterior derogat legi priori memuat prinsip-prinsip di antaranya:

a. Aturan hukum yang baru harus sederajat atau lebih tinggi dari aturan hukum yang lama.

b. Aturan hukum yang baru dan aturan hukum yang lama mengatur aspek yang sama.

Asas ini antara lain bermaksud mencegah dualisme yang dapat menimbulkan ketidakpastian hukum. Mengingat bahwa PP 24 dan PP 37 merupakan dalam peraturan perundang-undangan dalam hirarki yang sama.

Secara prinsip, ketentuan lama yang serupa tidak akan berlaku lagi pada saat aturan hukum baru mulai berlaku sehingga Undang-Undang yang berlaku belakangan membatalkan Undang-Undang terdahulu selama mengatur hal yang sama.

Selanjutnya dalam pembentukan Peraturan Pemerintah ini juga tidak sesuai dengan asas Pembentukan peraturan perundang-undangan yang diatur dalam Pasal 5 UndangUndang Nomor 12 tahun 2011 tentang Pembentukan Peraturan Perundang-Undangan, yaitu:

Pasal 5

Dalam membentuk Peraturan Perundang-undangan harus dilakukan berdasarkan pada asas Pembentukan Peraturan Perundang-undangan yang baik, yang meliputi:

a. kejelasan tujuan;

b. kelembagaan atau pejabat pembentuk yang tepat;

c. kesesuaian antara jenis, hierarki, dan materi muatan;

d. dapat dilaksanakan;

e. kedayagunaan dan kehasilgunaan; 
f. kejelasan rumusan; dan

g. keterbukaan.

Karena dalam praktiknya sejak diterbitkan pada tahun 2016 hingga saat ini, PP 24 khususnya Pasal 12 ayat (1) tidak dapat dilaksanakan, bahkan Peraturan Pemerintah ini telah diumumkan dalam Lembaran Negara Nomor 5893 yang artinya Peraturan Pemerintah tersebut telah berlaku mengikat umum sehingga wajib untuk dilaksanakan dan kejelasan rumusan dalam Peraturan Pemerintah ini masih menimbulkan ketidakpastian hukum pada pelaksanaan jabatan PPAT terkait daerah kerja yang masih satu wilayah kerja Kantor Pertanahan Kabupaten/Kotamadya atau telah menjadi Satuan Wilayah Provinsi.

Apabila asas dalam pembentukan peraturan perundang-undangan tidak ditaati, Menurut Amiroeddin Sjarif, akan dapat menimbulkan ketidaktertiban dan ketidakpastian dari sistem perundang-undangan, bahkan dapat menimbulkan kekacauan atau kesimpangsiuran perundang-undangan.

Dengan tidak dapat dilaksanakannya Pasal 12 ayat (1) dalam PP 24, menimbulkan ketidakpastian hukum terhadap Peraturan Pemerintah tersebut. Hal ini tidak sejalan dengan teori yang dipaparkan oleh Hans Kelsen, Menurut Hans Kelsen, hukum adalah sebuah sistem norma. Norma adalah pernyataan yang menekankan aspek "seharusnya" atau das sollen, dengan menyertakan beberapa peraturan tentang apa yang harus dilakukan. Undang-Undang yang berisi aturan-aturan yang bersifat umum menjadi pedoman bagi individu bertingkah laku dalam bermasyarakat, baik dalam hubungan dengan sesama individu maupun dalam hubungannya dengan masyarakat.

Aturan-aturan itu menjadi batasan bagi masyarakat dalam membebani atau melakukan tindakan terhadap individu. Adanya aturan itu dan pelaksanaan aturan tersebut menimbulkan kepastian hukum. Sedangkan Menurut Utrecht, kepastian hukum mengandung dua pengertian, yaitu pertama, adanya aturan yang bersifat umum membuat individu mengetahui perbuatan yang boleh atau tidak boleh dilakukan, dan kedua, berupa keamanan hukum bagi individu dari kesewenangan pemerintah karena dengan adanya aturan yang bersifat umum itu individu dapat mengetahui apa yang boleh dibebankan atau dilakukan oleh Negara terhadap individu. Oleh karena itu seharusnya Peraturan Pemerintah tersebut dapat memberikan kepastian agar Peraturan Pemerintah tersebut dapat menjadi pedoman bagi PPAT dalam melaksanakan jabatannya. 
Menurut Nazirwan ${ }^{15}$ Biro Hukum dan Hubungan Masyarakat, Kementrian Agraria dan Tata Ruang/Badan Pertanahan Nasional Republik Indonesia, bahwa PP 37 saat ini tetap berlaku karena statusnya juga tidak cabut karena dalam pembentukan PP 24, telah sesuai dengan Undang-Undang Nomor 12 Tahun 2011 tentang Pembentukan Peraturan PerundangUndangan, jika substansi yang diubah dibawah 50\% maka statusnya perubahan, tapi jika lebih dari 50\% substansi yang diubah maka peraturan yang lama statusnya dicabut.

Berdasarkan Undang-Undang Nomor 12 Tahun 2011 tentang Pembentukan Peraturan Perundang-Undangan terkait perencanaan dan penyusunan Peraturan Pemerintah, yaitu sebagai berikut :

Pasal 24,

Perencanaan penyusunan Peraturan Pemerintah dilakukan dalam suatu program penyusunan Peraturan Pemerintah.

Pasal 25,

(1) Perencanaan penyusunan Peraturan Pemerintah sebagaimana dimaksud dalam Pasal 24 memuat daftar judul dan pokok materi muatan Rancangan Peraturan Pemerintah untuk menjalankan Undang-Undang sebagaimana mestinya.

(2) Perencanaan sebagaimana dimaksud pada ayat (1) ditetapkan untuk jangka waktu 1 (satu) tahun.

\section{Pasal 26}

(1) Perencanaan penyusunan Peraturan Pemerintah sebagaimana dimaksud dalam Pasal 25 dikoordinasikan oleh menteri yang menyelenggarakan urusan pemerintahan di bidang hukum.

(2) Perencanaan penyusunan Peraturan Pemerintah sebagaimana dimaksud pada ayat (1) ditetapkan dengan Keputusan Presiden.

Pasal 27

Rancangan Peraturan Pemerintah berasal dari kementerian dan/atau lembaga pemerintah nonkementerian sesuai dengan bidang tugasnya.

\section{Pasal 28}

(1) Dalam keadaan tertentu, kementerian atau lembaga pemerintah nonkementerian dapat mengajukan Rancangan Peraturan Pemerintah di luar perencanaan penyusunan Peraturan Pemerintah.

(2) Rancangan Peraturan Pemerintah dalam keadaan tertentu sebagaimana dimaksud pada ayat (1) dibuat berdasarkan kebutuhan Undang-Undang atau putusan Mahkamah Agung. Pasal 29 Ketentuan lebih lanjut mengenai tata cara perencanaan penyusunan Peraturan Pemerintah diatur dengan Peraturan Presiden.

\footnotetext{
${ }^{15}$ Nazirwan, wawancara pribadi, Biro Hukum dan Hubungan Masyarakat, Kementrian Agraria dan Tata Ruang/Badan Pertanahan Nasional Republik Indonesia, Jakarta, 28 Mei 2019.
} 
Selanjutnya dalam Pasal 54 Undang-Undang Nomor 12 Tahun 2011 tentang Pembentukan Peraturan Perundang-Undangan terkait perencanaan dan penyusunan Peraturan Pemerintah, yang berbunyi:

\section{Pasal 54}

(1) Dalam penyusunan Rancangan Peraturan Pemerintah, pemrakarsa membentuk panitia antarkementerian dan/atau lembaga pemerintah nonkementerian.

(2) Pengharmonisasian, pembulatan, dan pemantapan konsepsi Rancangan Peraturan Pemerintah dikoordinasikan oleh menteri yang menyelenggarakan urusan pemerintahan di bidang hukum.

(3) Ketentuan lebih lanjut mengenai tata cara pembentukan panitia antar kementerian dan/atau antar non kementerian, pengharmonisasian, penyusunan, dan penyampaian Rancangan Peraturan Pemerintah diatur dengan Peraturan Presiden.

Pada intinya menurut Nazirwan ${ }^{16}$, saat ini baik PP 37 maupun PP 24 pada dasarnya masih sama-sama menjadi acuan pelaksanaan karena perubahannya hanya dibeberapa pasal, sehingga PP 37 tetap berlaku tapi terkait PP 24 terkait daerah kerja memang sulit untuk dilaksanakan, Nazirwan mengakui bahwa untuk pelaksanaannya memang agak sulit karena masih banyak yang perlu dipersiapkan, misalnya terkait akta yang dibuat dan pengawasan PPAT tersebut, kedepannya Kementrian ATR/BPN Republik Indonesia akan merubah dan merumuskan kembali terkait daerah kerja tersebut, kemudian akan dikembalikan sepeti aturan lama yakni Kabupaten/Kota.

Sejalan dengan itu Julius Purnawan ${ }^{17}$ selaku Ketua Ikatan Pejabat Pembuat Akta Tanah Pusat (IPPAT-Pusat) juga berpendapat bahwa hal yang belum atau tidak diatur secara spesifik tidak bertentangan peraturan selanjutnya maka akan tetap berlaku, jadi asas kelangsungan dari yang sebelum ke yang sesudah berlangsung sepanjang tidak bertentangan akan tetap berlaku, asas continuitas bahwa tidak hanya yang terakhir tapi sepanjang tidak diatur bertentangan maka akan tetap berlaku. Julius Purnawan justru mempertanyakan apabila Pasal 12 ayat (1) PP 24 diterapkan bagaimana mekanisme pembinaan dan pengawasan oleh Kantor Pertanahan.

Sebagaimana telah diatur dalam Pasal 4 sampai dengan Pasal 14 Peraturan Menteri Agraria Dan Tata Ruang/Kepala Badan Pertanahan Nasional Republik Indonesia Nomor 2

\footnotetext{
${ }^{16}$ Nazirwan, wawancara pribadi, Biro Hukum dan Hubungan Masyarakat, Kementrian Agraria dan Tata Ruang/Badan Pertanahan Nasional Republik Indonesia, Jakarta, 28 Mei 2019.

${ }^{17}$ Julius Purnawan, wawancara pribadi, Ketua Umum Ikatan Pejabat Pembuat Akta Tanah Pusat, Jakarta, 03 Mei 2019.
} 
Tahun 2018 Tentang Pembinaan Dan Pengawasan Pejabat Pembuat Akta Tanah, yaitu sebagai berikut :

Pasal 4

(1) Pembinaan dan pengawasan terhadap PPAT dilakukan oleh Menteri.

(2) Pembinaan dan pengawasan sebagaimana dimaksud pada ayat (1) di daerah dilakukan oleh Kepala Kantor Wilayah BPN dan Kepala Kantor Pertanahan.

Pembinaan

Pasal 5

(1) Pembinaan oleh Menteri sebagaimana dimaksud dalam Pasal 4 ayat (1), dapat berupa:

a. Penentuan kebijakan mengenai pelaksanaan tugas jabatan PPAT;

b. Pemberian arahan pada semua pihak yang berkepentingan terkait dengan kebijakan di bidang ke-PPAT-an;

c. Menjalankan tindakan yang dianggap perlu untuk memastikan pelayanan PPAT tetap berjalan sesuai dengan ketentuan peraturan perundang-undangan; dan/atau

d. Memastikan PPAT menjalankan tugas dan fungsi sesuai dengan Kode Etik.

(2) Pembinaan oleh Kepala Kantor Wilayah BPN dan Kepala Kantor Pertanahan sebagaimana dimaksud dalam Pasal 4 ayat (2), dapat berupa:

a. Penyampaian dan penjelasan kebijakan yang telah ditetapkan oleh Menteri terkait pelaksanaan tugas PPAT sesuai dengan ketentuan peraturan perundang-undangan;

b. Sosialisasi, diseminasi kebijakan dan peraturan perundang-undangan pertanahan;

c. Pemeriksaan ke kantor PPAT dalam rangka pengawasan secara periodik; dan/atau

d. Pembinaan terhadap pelaksanaan tugas dan fungsi PPAT sesuai Kode Etik.

Pasal 6

Selain pembinaan sebagaimana dimaksud dalam Pasal 5, Kepala Kantor Pertanahan atau petugas yang ditunjuk melakukan pemeriksaan atas akta yang dibuat oleh PPAT pada saat pendaftaran pemindahan hak dan pembebanan hak.

Pasal 7

(1) Kepala Kantor Wilayah BPN dan/atau Kepala Kantor Pertanahan melaksanakan pembinaan sebagaimana dimaksud dalam Pasal 5 ayat (2) sesuai dengan tugas dan kewenangannya.

(2) Pembinaan berupa penyampaian dan penjelasan kebijakan yang telah ditetapkan oleh Menteri terkait pelaksanaan tugas PPAT sesuai dengan ketentuan peraturan perundang-undangan dan sosialisasi, diseminasi kebijakan dan peraturan perundang-undangan pertanahan, dan pelaksanaan tugas dan fungsi PPAT sesuai dengan Kode Etik, dilaksanakan secara berkala.

(3) Pembinaan sebagaimana dimaksud pada ayat (2) dapat dibantu oleh Majelis Pembina dan Pengawas PPAT sesuai dengan tugas dan kewenangannya. 
Pengawasan

Pasal 8

Pengawasan terhadap PPAT sebagaimana dimaksud dalam Pasal 4, dapat berupa:

a. pengawasan terhadap pelaksanaan jabatan PPAT; dan

b. penegakan aturan hukum sesuai dengan ketentuan peraturan perundang-undangan di bidang PPAT.

Pasal 9

(1) Pengawasan terhadap pelaksanaan jabatan PPAT sebagaimana dimaksud dalam Pasal 8 huruf a dilakukan untuk memastikan PPAT melaksanakan kewajiban dan jabatan PPAT-nya sesuai dengan ketentuan peraturan perundang-undangan.

(2) Pelaksanaan jabatan sebagaimana dimaksud pada ayat (1) dapat berupa:

a. tempat kedudukan kantor PPAT;

b. stempel jabatan PPAT;

c. papan nama, dan kop surat PPAT;

d. penggunaan formulir akta, pembuatan akta dan penyampaian akta;

e. penyampaian laporan bulanan akta;

f. pembuatan daftar akta PPAT;

g. penjilidan akta, warkah pendukung akta, protokol atau penyimpanan bundle asli akta; dan

h. pelaksanaan jabatan lainnya yang ditetapkan oleh Menteri.

Pasal 10

(1) Pengawasan atas pelaksanaan jabatan PPAT sebagaimana dimaksud dalam Pasal 9 ayat (2) dilakukan dengan pemeriksaan ke kantor PPAT atau cara pengawasan lainnya.

(2) Pemeriksaan ke kantor PPAT atau cara lain sebagaimana dimaksud pada ayat (1) oleh:

a. Kepala Kantor Wilayah BPN, dilaksanakan secara berkala; dan

b. Kepala Kantor Pertanahan, dilaksanakan paling sedikit 1 (satu) kali dalam 1 (satu) tahun.

(3) Kepala Kantor Wilayah BPN dan/atau Kepala Kantor Pertanahan dapat menugaskan pejabat yang ditunjuk untuk melaksanakan pemeriksaan ke kantor PPAT.

(4) Dalam melakukan pemeriksaan sebagaimana dimaksud pada ayat (2), dapat dibantu oleh Majelis Pembina dan Pengawas PPAT sesuai dengan tugas dan kewenangannya.

(5) Dalam hal pemeriksaan ke kantor PPAT dibantu oleh Majelis Pembina dan Pengawas PPAT sebagaimana dimaksud pada ayat (4), dilaksanakan dengan ketentuan:

a. mendapat penugasan dari Ketua Majelis Pembina dan Pengawas PPAT; dan

b. dilakukan paling sedikit 2 (dua) orang.

(6) Hasil pemeriksaan dibuat dalam bentuk risalah sesuai dengan format tercantum dalam Lampiran I yang merupakan bagian tidak terpisahkan dari Peraturan Menteri ini.

(7) Dalam hal terdapat temuan pelanggaran yang dilakukan oleh PPAT, ditindaklanjuti dengan pemeriksaan oleh Majelis Pembina dan Pengawas PPAT. 
Pasal 11

(1) Hasil pemeriksaan ke kantor PPAT sebagaimana dimaksud dalam Pasal 10 dilaporkan secara berkala kepada Menteri.

(2) Pelaporan sebagaimana dimaksud pada ayat (1) dilakukan berjenjang, dengan ketentuan:

a. Kepala Kantor Pertanahan menyampaikan kepada Kepala Kantor Wilayah BPN, paling lambat pada minggu pertama awal bulan;

b. Kepala Kantor Wilayah BPN menyampaikan pelaporan di wilayahnya dan pelaporan dari Kantor Pertanahan kepada Direktur Jenderal, paling lambat pada minggu kedua awal bulan; dan

c. Direktur Jenderal meneruskan laporan Kepala Kantor Pertanahan dan Kepala Kantor Wilayah BPN kepada Menteri.

(3) Tindak lanjut pelaporan sebagaimana dimaksud pada ayat (2) sebagai pertimbangan dalam pengambilan kebijakan di bidang PPAT.

\section{Pasal 12}

(1) Pengawasan berupa penegakan aturan hukum sesuai dengan ketentuan peraturan perundang-undangan di bidang PPAT sebagaimana dimaksud dalam Pasal 8 huruf $\mathrm{b}$ dilaksanakan atas temuan dari Kementerian terhadap pelanggaran pelaksanaan jabatan PPAT atau terdapat pengaduan atas dugaan pelanggaran yang dilakukan oleh PPAT.

(2) Pelanggaran yang dilakukan oleh PPAT sebagaimana dimaksud pada ayat (1) merupakan:

a. pelanggaran atas pelaksanaan jabatan PPAT;

b. tidak melaksanakan kewajiban yang diatur dalam peraturan perundangundangan;

c. melanggar ketentuan larangan yang diatur dalam peraturan perundangundangan; dan/atau

d. melanggar Kode Etik.

(3) Pengaduan sebagaimana dimaksud dalam ayat (1) dapat berasal dari:

a. Masyarakat, baik perorangan/badan hukum; dan/atau

b.IPPAT.

(4) Pengaduan terhadap dugaan pelanggaran oleh PPAT dapat disampaikan secara tertulis kepada Kementerian atau melalui wehsite pengaduan, aplikasi Lapor atau sarana pengaduan lainnya yang disediakan oleh Kementerian.

(5) Dalam hal pengaduan dari masyarakat diterima oleh Kementerian, Kantor Wilayah BPN, Kantor Pertanahan, Majelis Pembina dan Pengawas PPAT atau IPPAT maka pengaduan diteruskan kepada MPPD.

(6) Pengaduan yang disampaikan secara tertulis oleh pelapor harus memenuhi syarat sebagai berikut:

a. harus jelas menyebutkan identitas pelapor dan terlapor; dan

b. melampirkan bukti yang berkaitan dengan pengaduan.

(7) MPPD menindaklanjuti laporan dugaan pelanggaran yang dilakukan oleh PPAT sebagaimana dimaksud pada ayat (2) dengan melakukan pemeriksaan terhadap PPAT terlapor. 
Banyak kendala-kendala sehingga Pasal 12 ayat (1) PP 24 karena pada dasarnya dalam pembentukan PP 24, Pemerintah tidak mempersiapkan terlebih dahulu segala persiapan untuk mendukung agar daerah kerja PPAT yang berubah menjadi lebih luas dapat berjalan sebagaimana yang diatur dalam Peraturan Pemerintah tersebut.

Menurut Nazirwan $^{18}$, bahwa kendala yang dihadapi hingga saat ini, PP 24 khususnya Pasal 12 ayat (1) Daerah Kerja PPAT yaitu Satuan Wilayah Provinsi belum dapat dilaksanakan karena PPAT sendiri maunya tetap kepada PP 37 yaitu Daerah Kerja PPAT adalah Kabupaten/Kotamadya, sejalan dengan Irwan Santosa ${ }^{19}$ yang merupakan Kepala Bidang Organisasi Ikatan Pejabat Pembuat Akta Tanah Pusat, menurut Irwan Santosa, IPPAT tidak sependapat atas terjadinya perubahan wilayah kerja PPAT menjadi satu provinsi. Hal tersebut karena mengakibatkan tidak meratanya penyebaran pekerjaan PPAT. Sehingga jika wilayah kerja PPAT satu provinsi pekerjaan-pekerjaan PPAT lebih banyak di dapat oleh PPAT senior. Sedangkan jika wilayah kerja hanya satu Kota/Kabupaten maka akan lebih terjadi pemerataan penyebaran pekerjaan PPAT sehingga menurut Nazirwan, Pimpinan Pusat IPPAT tidak merekomendasikan penerapan Pasal 12 ayat (1) PP 24 tersebut.

Menurut Julius Purnawan ${ }^{20}$, sepakat atau tidaknya IPPAT sangat bergantung dari kesiapan dari pelaksanaan dari Peraturan Pemerintah tersebut untuk dilaksanakan, apabila Pasal 12 ayat (1) PP 24 ingin dilaksanakan maka sistemnya harus dibuat dulu dengan rincian mekanismenya, tapi jika belum disiapkan maka IPPAT tidak sepakat karena banyak konsekuensi-konsekuensi yang bisa terjadi misalnya hanya dikuasai oleh segelintir PPAT yang mempunyai network yang bagus PPAT sedangkan PPAT yang lain yang tidak memiliki network tidak bisa bekerja.

Pertimbangan pemerintah mengapa PP 37 diubah dengan PP 24 karena Peraturan Pemerintah ini masuk dalam paket kebijakan deregulasi, Peraturan Pemerintah ini merupakan paket deregulasi pada tahun 2012.

\footnotetext{
${ }^{18}$ Nazirwan, wawancara pribadi, Biro Hukum dan Hubungan Masyarakat, Kementrian Agraria dan Tata Ruang/Badan Pertanahan Nasional Republik Indonesia, Jakarta, 28 Mei 2019.

${ }^{19}$ Irwan Santosa, wawancara pribadi, Bagian Organisasi Ikatan Pejabat Pembuat Akta Tanah Pusat, Jakarta, 13 Mei 2019.

${ }^{20}$ Julius Purnawan, wawancara pribadi, Ketua Umum Ikatan Pejabat Pembuat Akta Tanah Pusat, Jakarta, 03 Mei 2019.
} 
Menurut Nazirwan ${ }^{21}$, dalam pembentukan Peraturan Pemerintah biasanya IPPAT dilibatkan dalam pembentukannya, tapi karena PP 24 masuk dalam paket deregulasi dan prosesnya cepat jadi, sehingga tidak dapat dipastikan bahwa IPPAT dilibatkan atau tidak. Sedangkan menurut Irwan Sentosa ${ }^{22}$, mengatakan bahwa IPPAT sebagai organisasi satusatunya yang menaungi para PPAT di Indonesia selalu dilibatkan dalam penyusunan peraturan yang berkaitan dengan PPAT. Hal mana dapat dibuktikan dengan dilakukannya rapat bersama antara IPPAT dengan Kementerian ATR/BPN RI selaku pembina PPAT.

Berdasarkan Undang-Undang Nomor 12 tahun 2011 tentang Pembentukan Peraturan Perundang-Undangan bahwa dalam pembentukan Peraturan Pemerintah tersebut harus melibatkan masyarakat. Masyarakat sebagaimana dimaksud adalah "orang perseorangan atau kelompok orang yang mempunyai kepentingan atas substansi", sehingga dalam hal ini adalah IPPAT selaku pelaksana dari peraturan pemerintah tersebut.

Sebagaimana diatur dalam Pasal 96 Undang-Undang Nomor 12 tahun 2011 tentang Pembentukan Peraturan Perundang-Undangan terkait Partisipasi Masyarakat yang berbunyi:

\section{Pasal 96}

(1) Masyarakat berhak memberikan masukan secara lisan dan/atau tertulis dalam Pembentukan Peraturan Perundang-undangan.

(2) Masukan secara lisan dan/atau tertulis sebagaimana dimaksud pada ayat (1) dapat dilakukan melalui:

a. rapat dengar pendapat umum;

b. kunjungan kerja;

c. sosialisasi; dan/atau

d. seminar, lokakarya, dan/atau diskusi.

(3) Masyarakat sebagaimana dimaksud pada ayat (1) adalah orang perseorangan atau kelompok orang yang mempunyai kepentingan atas substansi Rancangan Peraturan Perundang-undangan.

(4) Untuk memudahkan masyarakat dalam memberikan masukan secara lisan dan/atau tertulis sebagaimana dimaksud pada ayat (1), setiap Rancangan Peraturan Perundang-undangan harus dapat diakses dengan mudah oleh masyarakat.

\section{B. Peran Ikatan Pejabat Pembuat Akta Tanah terkait PP 24}

Kebijakan perubahan wilayah kerja memiliki konsekuensi yang luas, pada dasarnya banyak hal yang perlu dipersiapkan, apalagi perubahan yang terjadi akan memberikan

\footnotetext{
${ }^{21}$ Nazirwan, wawancara pribadi, Biro Hukum dan Hubungan Masyarakat, Kementrian Agraria dan Tata Ruang/Badan Pertanahan Nasional Republik Indonesia, Jakarta, 28 Mei 2019.

${ }^{22}$ Irwan Santosa, wawancara pribadi, Bagian Organisasi Ikatan Pejabat Pembuat Akta Tanah Pusat, Jakarta, 13 Mei 2019.
} 
dampak yang cukup besar bagi pelaksana kebijakan tersebut, oleh karena itu dalam pembentukan peraturan perundang-undangan perlu keterlibatan masyarakat dalam pembentukannya karena sebagai pelaksana dari peraturan tersebut itu sendiri agar peraturan yang dibuat dapat berjalan secara efektif, oleh karena itu dalam pembentukan PP 24, IPPAT seharusnya dilibatkan karena sebagai pelaksana dari Peraturan Pemerintah tersebut.

Dalam pembentukan PP 24, menurut Julius Purnawan ${ }^{23}$ selaku ketua Ikatan Pejabat Pembuat Akta Tanah bahwa peran IPPAT terkait PP 24 yaitu memberikan pandangan atau masukan terkait PP 24 Terkait Daerah Kerja PPAT. Dalam hal ini Julius Purnawan memberikan pandangannya dan masukannya yaitu, antara lain:

"Pertama, butuh suatu sistem yang dapat terkoneksi secara luas, misalnya Information Technology (IT)/Teknologi Informasi, bantuan dari IT yang harus terintegrasi dalam sebuah kantor pertanahan yang sewilayah provinsi, jadi apabila daerah kerja akan berubah mejadi satuan Wilayah Provinsi sebaiknya mempersiapkan sistem berbasis pada IT dan tersinkronisasi terlebih dahulu yang dapat terakses keseluruh wilayah provinsi."

Hal ini juga berkaitan terkait pelaporan sebagai mana amanat dalam Pasal 26 Peraturan Pemerintah Nomor 24 Tahun 2016 tentang Perubahan Peraturan Pemerintah Nomor 37 Tahun 1998 tentang Peraturan Jabatan Pembuat Akta Tanah, yang berbunyi:

\section{Pasal 26}

(1) PPAT harus membuat satu buku daftar untuk semua akta yang dibuatnya.

(2) Buku daftar akta PPAT sebagaimana dimaksud pada ayat (1) diisi setiap hari kerja PPAT dan ditutup setiap akhir hari kerja dengan garis tinta yang diparaf oleh PPAT yang bersangkutan.

(3) PPAT wajib mengirim laporan bulanan mengenai akta yang dibuatnya, yang diambil dari buku daftar akta PPAT sebagaimana dimaksud pada ayat (1) kepada Kepala Kantor Pertanahan dan kantor-kantor lain sesuai ketentuan UndangUndang atau Peraturan Pemerintah yang berlaku selambat-lambatnya tanggal 10 bulan berikutnya.

Kedua, harus dibuatkan sistem dalam hal pelaksanaan oleh PPAT yang akan melaksanakan perbuatan hukum terhadap tanah yang berada diluar daerah tempat kedudukannya, sehingga apabila daerah kerja PPAT akan berubah menjadi satuan wilayah provinsi sebaiknya dibuatkan sistem terlebih dahulu, dapat tetap dibuat secara manual

\footnotetext{
${ }^{23}$ Julius Purnawan, wawancara pribadi, Ketua Umum Ikatan Pejabat Pembuat Akta Tanah Pusat, Jakarta, 03 Mei 2019.
} 
dimana pengecekan melalui PPAT tersebut sendiri atau boleh melalui rekan kerja di tempat tanah bersangkutan.

Berdasarkan Pasal 97 Peraturan Menteri Negara Agraria/Kepala Badan Pertanahan Nasional Nomor 3 Tahun 1997 tentang Ketentuan Pelaksanaan Peraturan Pemerintah Nomor 24 Tahun 1997 tentang Pendaftaran Tanah, yang mengatur sebagai berikut:

Pasal 97

(1) Sebelum melaksanakan pembuatan akta mengenai pemindahan atau pembebanan hak atas tanah atau Hak Milik Atas Satuan Rumah Susun PPAT wajib terlebih dahulu melakukan pemeriksaan pada Kantor Pertanahan mengenai kesesuaian sertipikat hak atas tanah atau Hak Milik Atas Satuan Rumah Susun yang bersangkutan dengan daftar-daftar yang ada di Kantor Pertanahan setempat dengan memperlihatkan sertipikat asli.

(2) Pemeriksaan sertipikat sebagaimana dimaksud pada ayat (1) dilakukan untuk setiap pembuatan akta oleh PPAT, dengan ketentuan bahwa untuk pembuatan akta pemindahan atau pembebanan hak atas bagian-bagian tanah hak induk dalam rangka pemasaran hasil pengembangan oleh perusahaan real estat, kawasan industri dan pengembangan sejenis cukup dilakukan pemeriksaan sertipikat tanah induk satu kali, kecuali apabila PPAT yang bersangkutan menganggap perlu pemeriksaan sertipikat ulang.

(3) Apabila sertipikat sebagaimana dimaksud pada ayat (1) sesuai dengan daftardaftar yang ada di Kantor Pertanahan, maka Kepala Kantor Pertanahan atau Pejabat yang ditunjuk membubuhkan cap atau tulisan dengan kalimat: "Telah diperiksa dan sesuai dengan daftar di Kantor Pertanahan" pada halaman perubahan sertipikat asli kemudian diparaf dan diberi tanggal pengecekan.

(4) Pada halaman perubahan buku tanah yang bersangkutan dibubuhkan cap atau tulisan dengan kalimat: PUSAT HUKUM DAN HUMAS BPN RI SJDI HUKUM "PPAT ...(nama PPAT ybs).... telah minta pengecekan sertipikat" kemudian diparaf dan diberi tanggal pengecekan.

(5) Apabila sertipikat sebagaimana dimaksud pada ayat (1) ternyata tidak sesuai dengan daftar-daftar yang ada di Kantor Pertanahan, maka diambil tindakan sebagai berikut:

a. apabila sertipikat tersebut bukan dokumen yang diterbitkan oleh Kantor Pertanahan, maka pada sampul dan semua halaman sertipikat tersebut dibubuhkan cap atau tulisan dengan kalimat : "Sertipikat ini tidak diterbitkan oleh Kantor Pertanahan .". kemudian diparaf.

b. apabila sertipikat tersebut adalah dokumen yang diterbitkan oleh Kantor Pertanahan akan tetapi data fisik dan atau data yuridis yang termuat di dalamnya tidak sesuai lagi dengan data yang tercatat dalam buku tanah dan atau surat ukur yang bersangkutan, kepada PPAT yang bersangkutan diterbitkan Surat Keterangan Pendaftaran Tanah sesuai data yang tercatat di Kantor Pertanahan dan pada sertipikat yang bersangkutan tidak dicantum-kan sesuatu tanda.

(6) Sertipikat yang sudah diperiksakan kesesuaiannya dengan dafar-daftar di Kantor Pertanahan tersebut dikembalikan kepada PPAT yang bersangkutan. 
(7) Pengembalian sertipikat sebagaimana dimaksud pada ayat (6) dilakukan pada hari yang sama dengan hari pengecekan.

(8) Penerbitan SKPT sebagaimana dimaksud pada ayat (5) huruf b dilakukan selambatlambatnya dalam 7 (tujuh) hari kerja terhitung dari hari pengecekan.

Ketiga, mempersiapkan mekanisme pembinaan dan pengawasan oleh Kantor Pertanahan, karena tugas Kantor Pertanahan itu melakukan pembinaan dan pengawasan terhadap PPAT yang satu tempat kedudukan dengan kantor pertanahan atau kantor pertanahan boleh memeriksa PPAT yang melakukan perbuatan hukum terhadap tanah yang satu tempat kantor pertanahan.

Keempat, apabila dipersiapkan nanti perwilayah apakah seluruh PPAT harus merubah SK karena didalam SK telah ditentukan tempat kedudukannya Kabupaten/Kotamadya terus apakah PPAT terssbut perlu dilantik ulang. Sehingga IPPAT dalam hal ini menyarankan agar Kementrian ATR/BPN mempersiapkan dulu perangkatnya sampai perangkatnya siap dan lancar, apabila tidak lancar karena akan berpotensi untuk dirubah lagi .

Berdasarkan Aturan Kepala Badan Pertanahan Nasional Nomor 1 Tahun 2006 tentang Ketentuan Pelaksanaan Peraturan Pemerintah Nomor 37 Tahun 1998 tentang Peraturan Jabatan Pejabat Pembuat Akta Tanah bahwa Syarat dan Tata Cara Pengangkatan PPAT, yaitu sebagai berikut:

berikut:

\section{Pasal 15}

(1) Calon PPAT yang telah lulus ujian PPAT sebagaimana dimaksud dalam Pasal 11 ayat (2), mengajukan permohonan pengangkatan sebagai PPAT kepada Kepala Badan sesuai bentuk sebagaimana tercantum dalam Lampiran I.

(2) Permohonan pengangkatan sebagai PPAT, dilengkapi dengan persyaratan :

a. Surat Keterangan Catatan Kepolisian (SKCK) dan/atau surat keterangan yang pada intinya menerangkan tidak pernah melakukan tindak pidana kejahatan yang dikeluarkan oleh Instansi Kepolisian;

b. Surat keterangan kesehatan dari dokter umum atau dokter spesialis yang menyatakan bahwa yang bersangkutan sehat jasmani dan rohani;

c. Surat pernyataan bermaterai cukup dari yang bersangkutan yang menyatakan kesediaannya untuk ditunjuk sebagai penerima protokol PPAT lain;

d. Surat pernyataan bermeterai cukup dari yang bersangkutan yang menyatakan tidak rangkap jabatan;

e. fotocopy sertifikat Pendidikan dan Pelatihan Pertama PPAT yang dilegalisir oleh pejabat yang berwenang;

f. daftar riwayat hidup; dan

g. fotocopy ijazah Program Pendidikan Spesialis Notariat atau Magister Kenotariatan yang dilegalisir oleh pejabat yang berwenang; atau 
h. fotocopy ijazah S1 dan Program Pendidikan Khusus PPAT yang diselenggarakan oleh lembaga pendidikan tinggi yang dilegalisir oleh pejabat yang berwenang.

\section{Pasal 16}

Berdasarkan permohonan pengangkatan PPAT sebagaimana dimaksudkan dalam Pasal 15, Kepala Badan menerbitkan Keputusan Pengangkatan PPAT.

Pasal 17

(1) Bagi calon PPAT yang akan diangkat sebagai PPAT, sebelum melaksanakan tugasnya wajib mengikuti pembekalan tehnis pertanahan yang diselenggarakan oleh Badan Pertanahan Nasional Republik Indonesia yang penyelenggaraannya dapat bekerja sama dengan organisasi profesi PPAT.

(2) Keputusan pengangkatan PPAT sebagaimana dimaksud dalam Pasal 16 diberikan kepada yang bersangkutan setelah selesai pelaksanaan pembekalan tehnis pertanahan.

(3) Tembusan keputusan pengangkatan PPAT sebagaimana dimaksud dalan Pasal 16 disampaikan kepada pemangku kepentingan.

(4) Untuk keperluan pelantikan dan pengangkatan sumpah jabatan PPAT, setelah menerima keputusan pengangkatan sebagaimana dimaksud pada ayat (2), calon PPAT wajib melapor kepada Kepala Kantor Pertanahan setempat paling lambat 3 (tiga) bulan.

(5) Apabila calon PPAT tidak melapor dalam jangka waktu sebagaimana dimaksud pada ayat (4), maka keputusan pengangkatan PPAT yang bersangkutan dibatalkan demi hukum.

Lanjut menurut Julius Purnawan bahwa perubahan daerah kerja tersebut harus berdasarkan Peraturan Menteri, sehingga perlu disosialisasikan dulu, apabila belum ada Peraturan Menterinya bisa dilakukan uji coba terlebih dahulu, dibuatkan Pilot Profect-nya sehingga apabila telah dikeluarkan Peraturan Menteri jangan sampai ada gejolak baru dibatalkan, terus dikeluarkan lagi aturan yang baru, sehingga perlu disosialisasikan dan di ujicoba dulu sistem serta mekanisme lancar dan bisa memberikan jaminan jangka panjang yang bagus sampai tidak ada permasalahan sehingga dapat dijalankan.

Sejalan dengan ini Irwan Sentosa ${ }^{24}$ bahwa peran IPPAT sejauh ini yaitu dalam pembentukan PP 24, IPPAT memberikan masukan-masukan tentang permasalahanpermasalahan hukum dalam praktik yang dilakukan oleh PPAT kepada Kementerian ATR/BPN RI. Jadi PP 24 lebih komprehensif dalam menerapkan peraturan ke PPAT-an tapi menurut Irwan Santosa Pengurus Pusat IPPAT tidak merekomendasikan penerapan PP 24

\footnotetext{
${ }^{24}$ Irwan Santosa, wawancara pribadi, Bagian Organisasi Ikatan Pejabat Pembuat Akta Tanah Pusat, Jakarta, 13 Mei 2019.
} 
terkait Pasal 12 ayat (1). Hal tersebut dikarenakan dapat mengakibatkan terjadinya keresahan di kalangan anggota IPPAT, karena dominasi pekerjaan dapat dilakukan oleh PPAT senior.

\section{PENUTUP}

PP 24 Terkait Daerah Kerja PPAT tidak dilaksanakan karena masih banyak yang perlu dipersiapkan untuk mendukung pelaksanaan Peraturan Pemerintah tersebut dan PPAT sendiri ingin tetap mengacu pada Pasal 12 ayat (1) PP 37 bahwa Daerah kerja PPAT adalah satu wilayah kerja Kantor Pertanahan Kabupaten/Kotamadya.

Peran Ikatan Pejabat Pembuat Akta Tanah terkait PP 24 Terkait Daerah Kerja PPAT yaitu memberikan pandangan dan masukan kepada pemerintah dalam hal ini Kementerian ATR/BPN serta membantu pemerintah dalam mensosialisasikan setiap peraturan baru yang dikeluarkan terkait dengan profesi PPAT.

Kedepannya Kementrian ATR/BPN RI harus segera merubah atau merumuskan kembali terkait daerah kerja ini apakah akan dikembalikan sepeti aturan lama yakni Kabupaten/Kota atau Satuan Wilayah Provinsi apabila ingin tetap pada Satuan Wilayah Provinsi maka pemerintah Segera mengeluarkan Petunjuk Teknis/petunjuk pelaksanaan terkait Pasal 12 ayat (1) tentang Daerah Kerja tersebut dan mempersiapkan dulu setiap perangkat atau sistem yang diperlukan agar dalam pelaksanaannya telah siap dan dapat berjalan lancar.

Dalam penyusunan Peraturan-peraturan yang terkait dengan Pejabat Pembuat Akta Tanah agar selalu melibatkan IPPAT, baik dalam sosialisasi, koordinasi, dan publikasi karena IPPAT sebagai pelaksana dari peraturan tersebut.

\section{DAFTAR PUSTAKA}

\section{Buku-Buku:}

Abdulkadir, Muhammad, Hukum dan Penelitian Hukum, Bandung: Citra Aditya Bakti, 2004.

Ali, Achmad, Menguak Tahir Hukum (Suatu Ka)ian Filosofis dan Sosiologis), Jakarta, Toko Gunung Agung, 2002.

Huda, Ni(matul, Teori \& Pengujian Peraturan Perundang-Undangan, Bandung; Nusamedia, 2011.

Marzuki, Peter Mahmud, Pengantar Ilmu Hukum, Jakarta; Kencana, 2008. 
Samsaimun, Peraturan Jahatan PPAT, Pengantar Peraturan Jahatan Pejahat Pemhuat Akta Tanah (PPAT) dalam peralihan Hak atas Tanah di Indonesia, Bandung; Pustaka Reka Cipta, 2018.

Sjarif, Amiroeddin, Perundang-Undangan (Dasar,Jenis,dan Teknik Memhuatnya), Bandung: Rineka Cipta, 1987.

Sinamo, Nomensen, Ilmu Perundang-Undangan, Jakarta: Jala Permata Aksara, 2016.

Sugiarto, Umar Said, Pengantar Hukum Indonesia, Jakarta: Sinar Grafika, 2016.

Syahrani, Riduan, Rangkuman Intisari Ilmu Hukum, Bandung; Citra Aditya Bakti, 1999.

Wawancara:

Nazirwan, Biro Hukum dan Hubungan Masyarakat, Kementrian Agraria dan Tata Ruang/Badan Pertanahan Nasional Republik Indonesia.

Julius Purnawan, Ketua Umum Ikatan Pejabat Pembuat Akta Tanah Pusat.

Irwan Santosa, Kepala Bagian Organisasi Ikatan Pejabat Pembuat Akta Tanah Pusat. 